Bull. Pharm. Sci., Assiut University

vol. 10, Part 1, pp 95-111 (1987)

\title{
ON THE INTERACTION BETWEEN RIFAMPICIN AND MACROMOLECULES
}

\section{MYRJS AND BRIJS.}

S. Ismail, F.S. Habib, S. El-Shanawany and E.A. Fouad. Dept. of Pharmaceutics, Faculty of Pharmacy, Assiut University Assiut, Egypt.

\section{ABSTRACT}

The permeation rate constant of rifampicin in presence of Myrj 52, Myrj 53, Myrj 59, Brij 35 and Brij 58 was studied utilizing the dynamic dialusis technique. The presence of Myrjs or Brijs in rifampicin solution markedly decreased the permeation rate constant. Generally, the apparent transfer rate constant is inversely proportional to the surfactant concentration. The most reducing effect was exhibited in case of Brij 35. This may be due to a high affinity of the drug to interact with this surfactant rather than the other tested ones.

The Langmuir plots for the interaction between rifampicin and surfactant showed $y$-intercept indicating that the complex formation is a factor in the binding of rifampicin by surfactants. Furthermore, the presence of surfactant in rifampicin solution was found to reduce its antibacterial activity against $\underline{S}$. aureus.

\section{INTRODUCT ION}

The effect of surfactant on the biological availability and pharmacological activity of drugs has attracted the attention of researchers ${ }^{l}$. The phenomena of drug macromolecule interaction have received a wide attention in recent years in the view of their relevance to drug absorption, transport, and overall availability. Dynamic aialysis techniques have been successfully, applied to study such interactions ${ }^{2-8}$. 


\section{S.Ismail et al}

The application of such techniques purportedly offers some advantages like, rapidity, simplicity and economy over the time honored techniques but it is limited by the fact that porous dialysis membranes are permeable to many macromolecules of pharmaceutical interest.

Cellophane membranes are widely used in the dynamic ${ }^{6-8}$ and equilibrium ${ }^{9-10}$ dialysis. Also, cellophane membrane has been used to study the effect of surfactants on the diffusion characteristics of the drugs across the membranes ${ }^{1-13}$. There is some controversy concerning the permeability of cellophane dialysis membrane to nonionic surfactants. Breuninger and Goettsch 9 found that, although visking cellophane membrane was permeable to polysorbate 80, Fisher cellophane membrane was impermeable to the same surfactant. The same observation was also found by Pa$\operatorname{tel}^{14}$ who demonstrated that cellophane membrane was impermeable to cetomacrogol and polysorbate 80 .

In the present investigation a dynamic dialysis technique was utilized to find out information regarding the extent of binding of rifampicin with some selected nonionic surfactants, namely, Myrj 52, Myrj 53, Myrj 59, Brij 35 and Brij 58. The surfactants were used in a concentration range (0.2-0.6\% w/v) above their respective CMC values. The selection of those surfactants was based on the consideration that, rifampicin, a slightly water soluble drig, is characterized by having a relative proton donating power, while the selected surfactants are having a nucleophilic oxygen in each ethylene oxide unit. Therefore, the binding tendency which rifampicin exhibits for those surfactants was studied. Also, the study was concerned with the effect of surfactant concentration on the antimicrobial activity of rifampicin against $\underline{\text { s. aureus }}$. 
On the Interaction Between Rifampicin and Macromolecules II. Myrjs and Brij:

\section{EXPER I MENTAL}

\section{Materials:}

Rifampicina, Myrj $52^{b}, \operatorname{Myrj} 53^{b}, \operatorname{Myrj} 59^{b}, \operatorname{Brij} 35^{b}$ and Brij $58^{b}$, Standard cellophane membrane ${ }^{C}(30 / 32)$, Gelatin ${ }^{d}$ and $s$. aureus (standard grade).

\section{Methodology:}

\section{1- Dynamic Dialysis Study.}

The experimental system, the general protocol and the treatment of the data were described in detail previously ${ }^{6}$. Generally, the system was preparea to contain $5 \mathrm{ml}$ of rifampicin solution, $200 \mathrm{mcg} / \mathrm{ml}$, eitner alon 3 or in presence of the tested surfactant, in the inner compartment. The inner compartment was placed into the outer compartment, which contains $20 \mathrm{ml}$ distilled water, in such a manner that the surface levels of the two compartments are the same. The upper side of the inner compartment was covered with a thinly perforated nylon membrane so as to keep the volume of rifampicin solution constant, in the inner compartment, during the expermintal study. The dialyzing i itits were placed in a thermostatically controlled water bath oscillator, prsviously adjusted at $37^{\circ} \mathrm{C} \pm 0.2^{\circ} \mathrm{C}$ and at $50 \mathrm{rpm}$.

At suitible time intervals, the amount of rifampicin diffused into the acceptor was determined spectrophotometrically at $330 \mathrm{~nm}$ against a blank similarly treated. It should be noted that each experiment was done in triplicaie and the average concentration was calculated.

\section{2- Antimicrobial Activity.}

The antimicrobial activity of rifampicin was determined in absence and

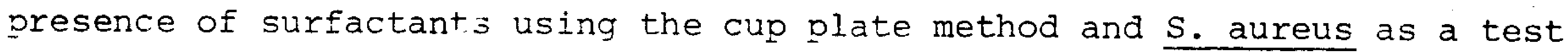
a) Lepetit, Italy
b) ICI, USA.
c) Fisher Sci., Co., London.
d) Merck. 
microorganism ${ }^{15}$. The antibacterial activity of rifampicin solution was measured as zones of inhibition around the wells after 24 hours of incubation at $37^{\circ} \mathrm{C}$. Each experiment was run in triplicate and the diameter of zones of inhibition was calculated. It should be noted that rifampicin was used in a concentration of $5 \mathrm{mcg} / \mathrm{ml}$, and the volume placed into each well was $0.1 \mathrm{ml}$. S. aureue was used as a test organism since it is not pathogenic and sensitive to the arug.

\section{RESULTS AND DISCUSSION}

Figures $1-5$ show the results of permeation rate of rifampicin either alone or in presence of different concentrations of Myrjs or Brijs. The plots are expressed in terms of log o retained concentration versus time. In all cases, a linear relationship was observed. These lines showed progressive decreasing slopes with an increase in the surfactant concentration. The decreased slopes, observed in presence of surfactants, provide an evidence for an interaction between rifampicin and surfactants.

Indeed, the permeation rate of the drug in the absence of macromolecules can be described by the following equation:

$$
\frac{\mathrm{dC}_{t}}{\mathrm{dt}}=\mathrm{kc} \quad \ldots \ldots \ldots \ldots \ldots \text { eq. } 1
$$

where, $C_{t}$ is the total drug concentration in the donor compartment. on the other hand, the diffusion of the drug in presence of a macromolecule, the above equation becomes:

$$
-\frac{d C_{f}}{d t}=\mathrm{kC}_{f} \quad \ldots \ldots \text { eq. } 2
$$

where $c_{f}$ is the concentration of unbound drug inside the donor compartment. The following expression which describes the rate of disappearance of the drug from the cell as a function of its total $\left(c_{t}\right)$, bound $\left(C_{b}\right)$ and free $\left(C_{f}\right)$ concentrations can be obtained from 
On the Int action Between Rifampicin and Macromolecules II. Muris and Brijs.

eq. 2 considering that $c_{t}=c_{b}+c_{f}$

$$
-\frac{d C_{t}}{d t}=\frac{K C_{t}}{1+R} \quad \therefore \ldots \text { eq. } 3
$$

where, $R$ is the ratio between $C_{b}$ and $C_{f}$.

As shown from Figs. $1-5$ that the permeation process in presence of macromolecules follows first order kinetics. This suggests that $c_{b} / c_{f}$ remains constant during each experiment. This could be explained on the basis that, at a given pH value and temperature rifampicin distributes itself between the micellar and the intermicellar phases with a constant value. In a previous study ${ }^{16}$, it was found that the partition coefficient of ethacrynic acid between micellar and aqueous phases of polysorbates was foun to be $\mathrm{pH}$ dependent as well as on the nature of surfactant used.

The diffusion rate constants of rifampicin through the standard cellophane membrane, in presence of aifferent concentrations of Myrjs are surveyed in Table 1.

From the above table it could be observed that the diffusion rate constant is markedly dependent on the surfactant tyoe and concentration. In all ases the rate constant is less than that of the control. Actually, it was found that Brijs delayed the diffusion of the drug across the semipermeable membrane, in a magnitude les than that exhibited by Myrjs. This may be due to a high affinity of rifampicin to interact with Brijs rather than Myrjs.

Figures 6 and 7 are the Lanamuir plots for the binding of rifampicin by Myrjs and Brijs. The data, of the equilibrium dialysis, are plotted in this manner so as to obtain the limiting binding capazity of the surfactant unit weight at an infinitely high rifampicir concentration. The plots were found to be in obedience with the Ellowing Langmuir equation ${ }^{17}$ :

$$
\frac{M}{x}=\frac{1}{a b} \cdot \frac{1}{C_{e}}+\frac{1}{a}
$$




\section{S. Ismail $\underline{\text { et }} \underline{\text { al }}$}

where, $m$ is the weight of macromolecule, in grams, $x$ is the amount of the drug adsorbed, $c_{e}$ is the equilibrium concentration of the free drug, a is the amount of the drug adsorbed when the entire surface of the adsorbent is covered by a monolayer and b is the equilibrium constant for the adsorption process. The Y-intercept is the reciprocal of the limiting quantity of rifampicin bound per gram of surfactant.

The graph is of particular interest in the present investigation, since the existence of the Y-intercept suggests that complex formation is a factor in the binding of rifampicin by the macromolecule. If the sole interaction in the system is the partitioning of the drug into the micelle, the expected curve will be a straight line passing through the origin.

The binding tendency which rtfampicin exhibits for the investigated macromolecules is dependent on the type of surfactant used. The limiting adsorption capacity in case of Brij 35 and Brij 58 are nearly the same $\left(\sim 2 \times 10^{-6}\right)$. Contrary, in case of Myrjs the limiting adsorption capacity was found to be dependent on the type of Myrj. The high limiting adsorption capacity was observed in case of Myrj $53\left(/^{\prime 2} \times 10^{-6}\right)$ and the lowest one was exhibited by Myrj $59\left(\cdots 1 \times 10^{-6}\right)$.

The antimicrobial activity of rifampicin solution $0.5 \mathrm{mcg} / \mathrm{ml}$ ) was determined either alone or in presence of different surfactant concentrations. The data, surveyed in Table 2 , revealed that as the surfactant concentration was increased the diameter of the inhibition zone was decreased as compared with that of the control. This could be explained on the basis that most of rifampicin molecules are burried inside the micellar core of the surfactant and the free part still antimicrobially active. The concentration of the free part in the intermicellar phase is mainly dependent on the distribution coefficient of the drug between the micellar and 
On the Interaction Between Rifampicin and Macromolecules II. Myrjs and Brijs.

the aqueous phases. Further studies will be carried out so as to estimate the distribution coefficient of rifampicin between the micellar and the aqueous phases of those surfactants.

It is worthy to note that the investigated macromolecules were tested for their permeation across the cellophane membrane. Frotunately, It was found that those surfactants were not capable to aass through the membrane. 
S. Ismail et al

Table 1 : Effect of Surfactant Concentration on the Permeation Rate Constant ( $\mathrm{K} \times 10^{4} \mathrm{hr}^{-1}$ ) of Rifampicin through a Standard Cellophane Membrane at $37^{\circ} \mathrm{C}$.

\begin{tabular}{|c|c|c|c|c|}
\hline \multirow[t]{2}{*}{ Surfacta } & \multicolumn{4}{|c|}{$\begin{array}{c}\mathrm{K} \times 10^{4} \mathrm{hr}^{-1} \text { in presence of following surfactant concentra- } \\
\text { tions }(\% \mathrm{w} / \mathrm{v}):\end{array}$} \\
\hline & 0 & 0.2 & 0.4 & 0.6 \\
\hline Myrj 52 & 419 & 421 & 311 & 256 \\
\hline Myrj 53 & 419 & 368 & 262 & 229 \\
\hline Myrj 59 & 419 & 390 & 363 & 295 \\
\hline Brij 35 & 419 & 181 & 110 & 141 \\
\hline Brij 58 & 419 & 191 & 125 & 100 \\
\hline
\end{tabular}

Table 2 : Effect of Sufactant Concentration on the Antibacterial Activity of Rifampicin.

Inhibition zone (mm) in presence of the following Surfa-

Surfactant ctant concentrations $(8 \mathrm{w} / \mathrm{v})$ :

- - - - - -

$\begin{array}{lllll} & 0.2 & 0.5 & 1.0 & 1.5 \\ \text { Myrj } 52 & 29 & 29 & 29 & 29 \\ \text { Myrj } 53 & 32 & 31 & 28 & 25 \\ \text { Myrj } 59 & 28 & 28 & 27 & 26 \\ \text { Brij } 35 & 32 & 30 & 27 & 25 \\ \text { Brij } 58 & 32 & 32 & 30 & 29\end{array}$

N.B. The ribition zone for rifampicin in absence of surfactant is $33 \mathrm{~mm}$. 
On the in draction Between Rifampicin and Macromolecules 11 . Myrjs and Brijs

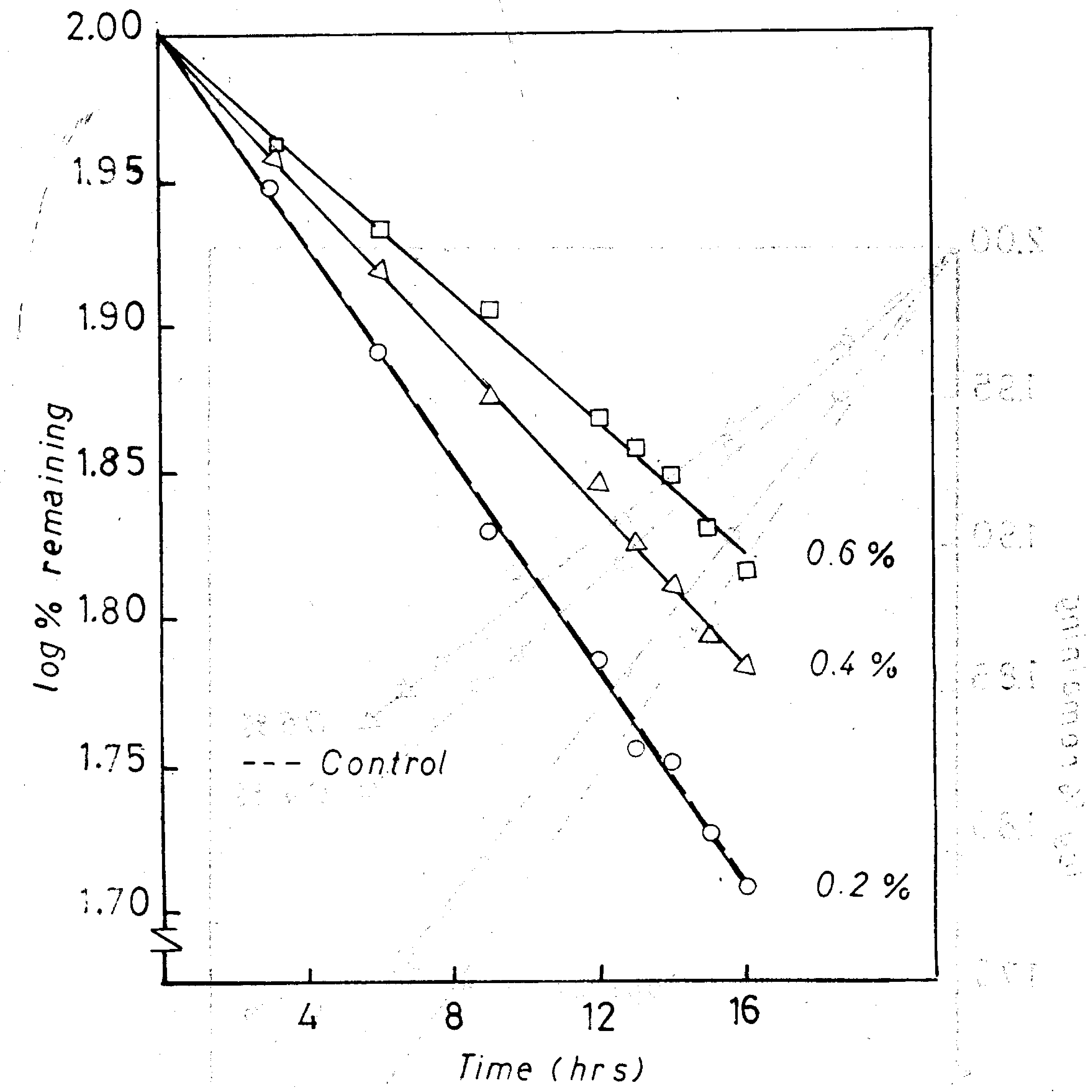

FIGURE : First-order plots for Permeation of Rifampicin through a Standard Cellophane Membrane in Presence of Different Concentrations of Myri 52 . 
S. Ismail et al

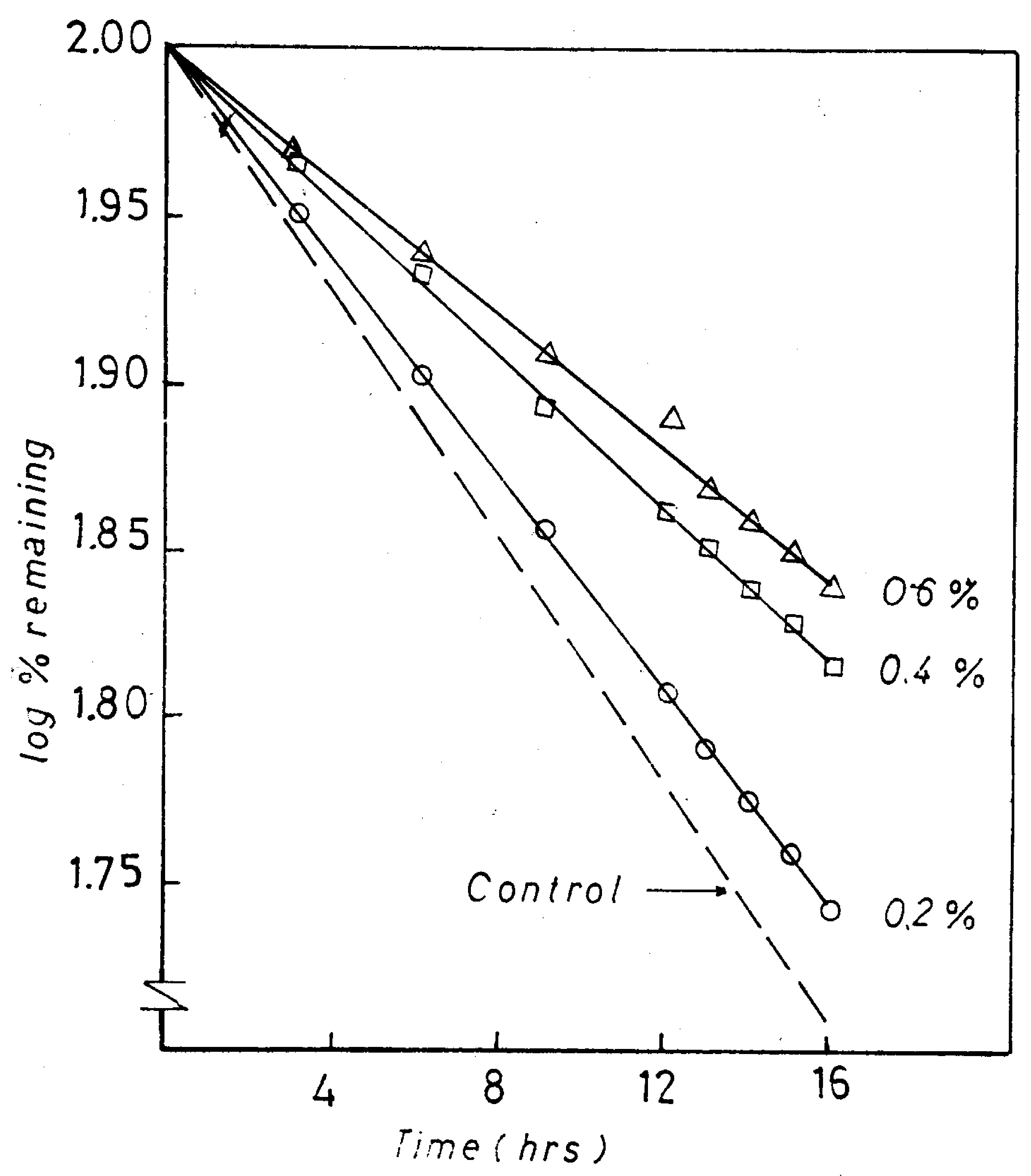

FIGURE 2: First-order Plots for Permeation of Rifampicin through a Standard Cellophane Membrane in Presence of Different concentrations of Myrj 53. 
On the Interaction Between Rifampicin and Macromolecules II. Myrjs and Brijs.

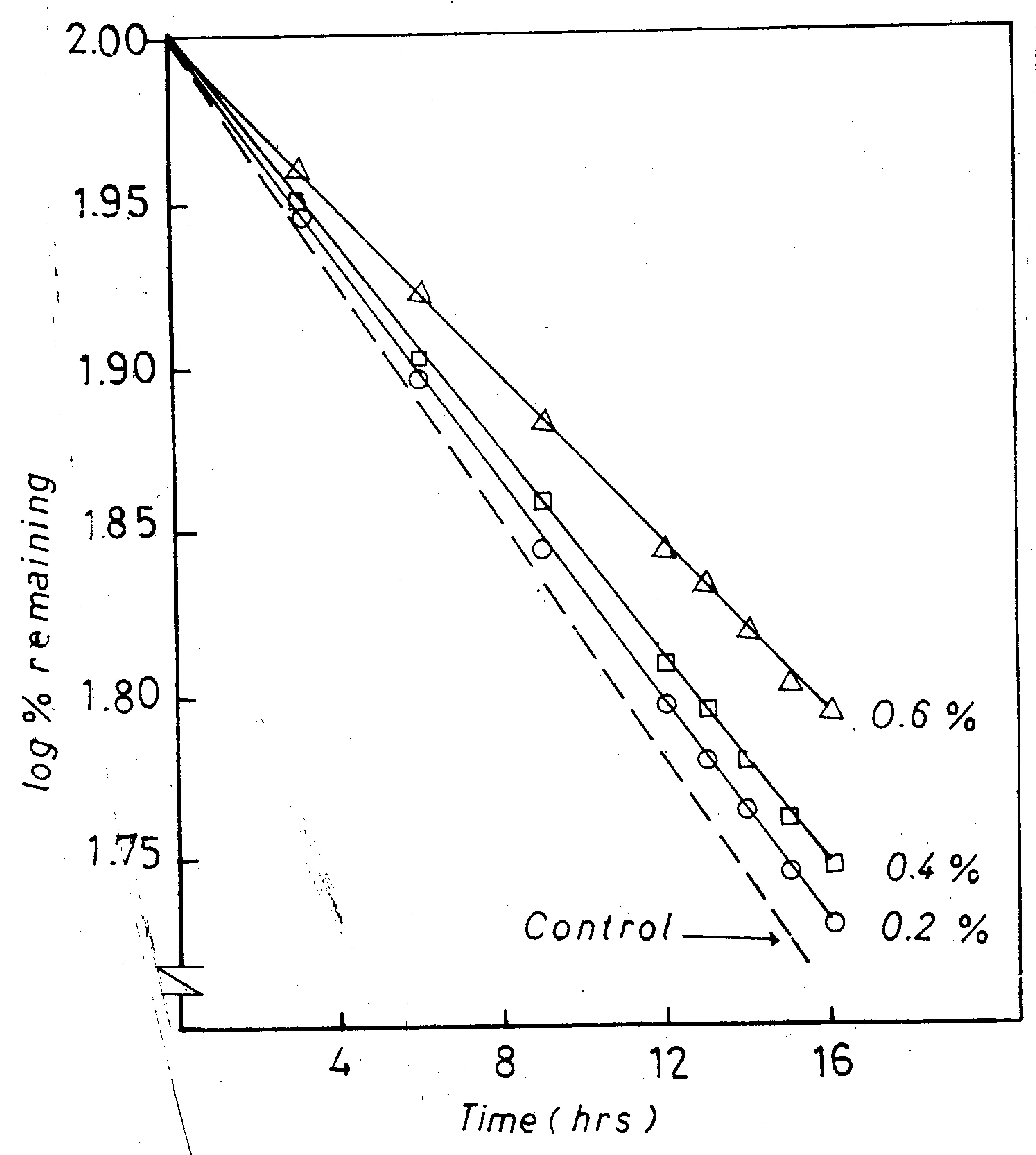

FIGURE 3: First-order Plots for Permeation of Rifappicin through a Standara Cellophane Membrane in Presence of Different concentrations of Myrj 59. 
S.Ismail et al

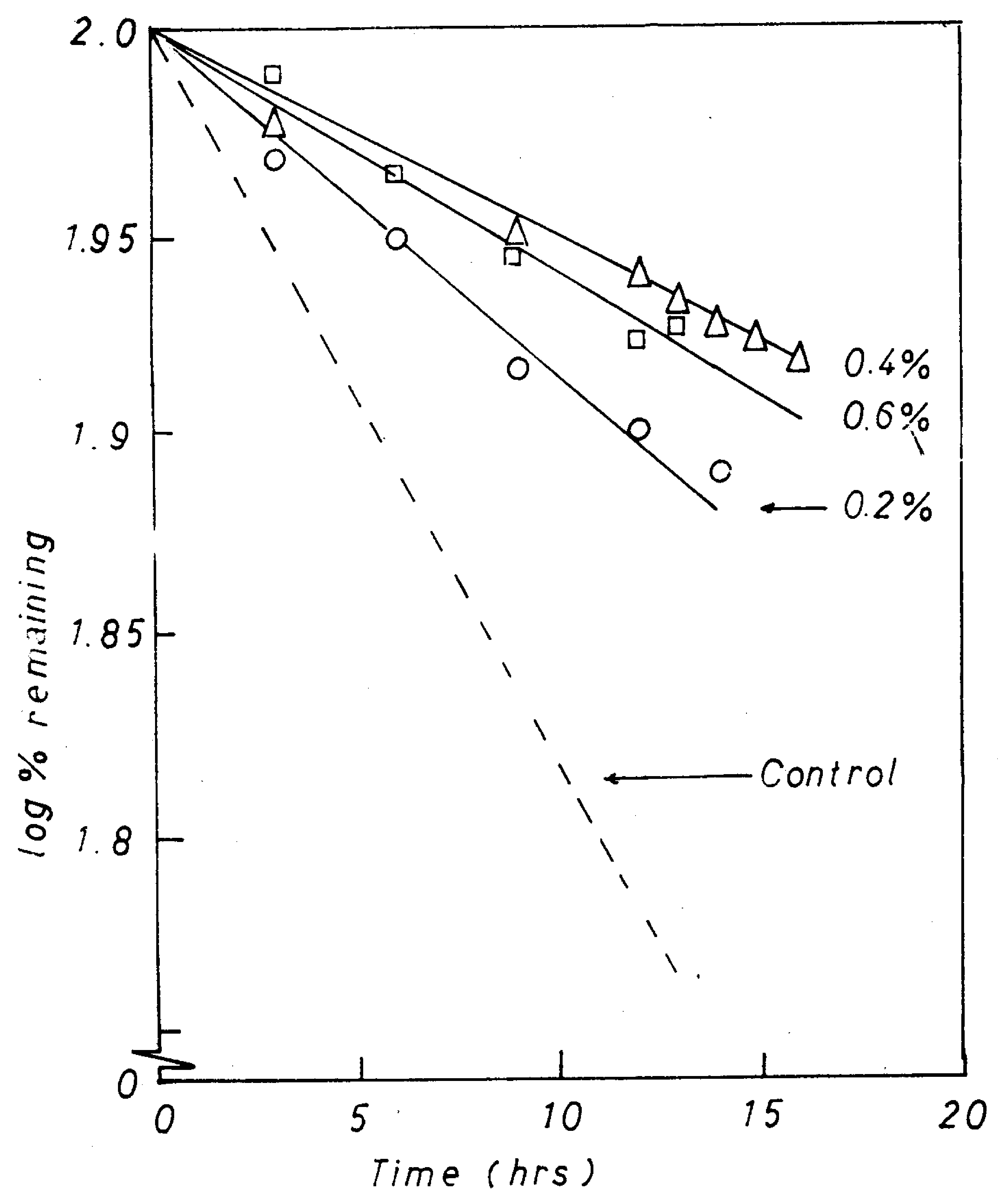

FIGUPE 4: First-order Plots for Permeation of Rifampicin through a Standard Cellophane Membrane in Presence of Different Concentrations of Brij 35 . 
On the Interaction Between Rifampicin and Macromolecules II. Myrjs and Brijs

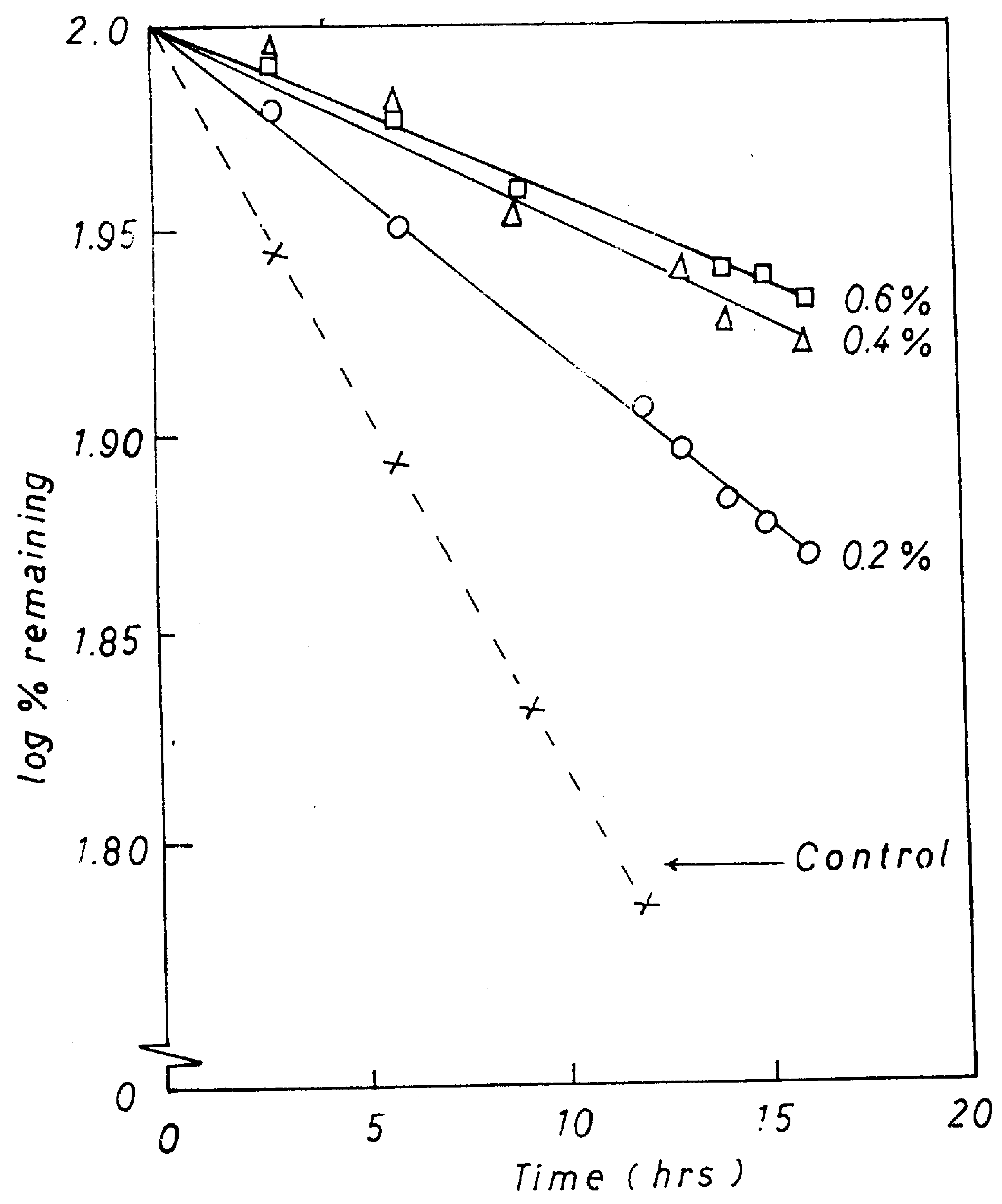

FIGURE 5: First-order Plots for Permeation of Rifampicin through a standard Cellophane Memorane in Presence of Different Concentrations of Brij 58 . 


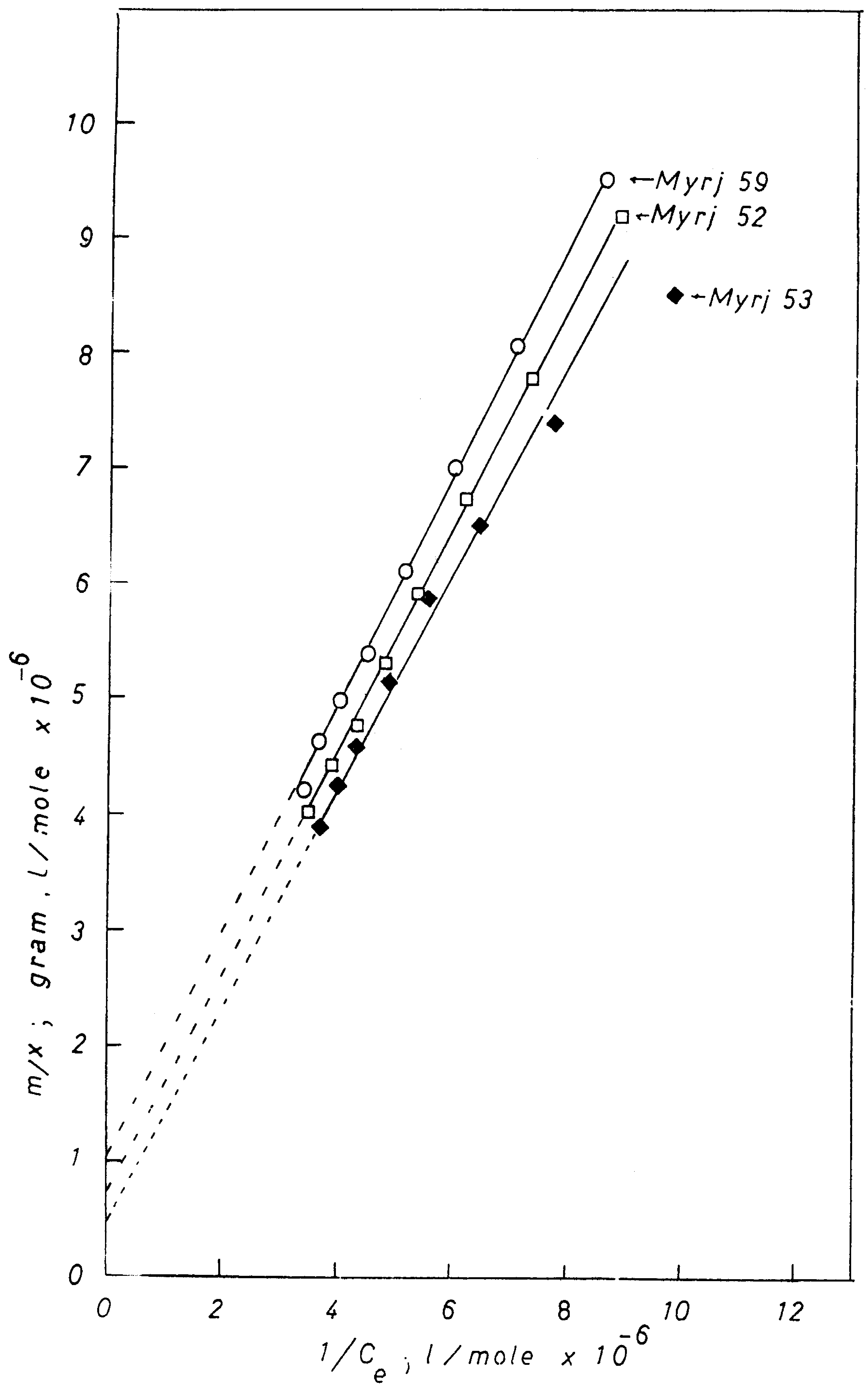

FIGURE 6: Tangmuir Plots for the Interaction between Rifampicin and Mrjo. 
On the Interaction Between Rifampicin and Macromolecules II. Myrjs and Brijs

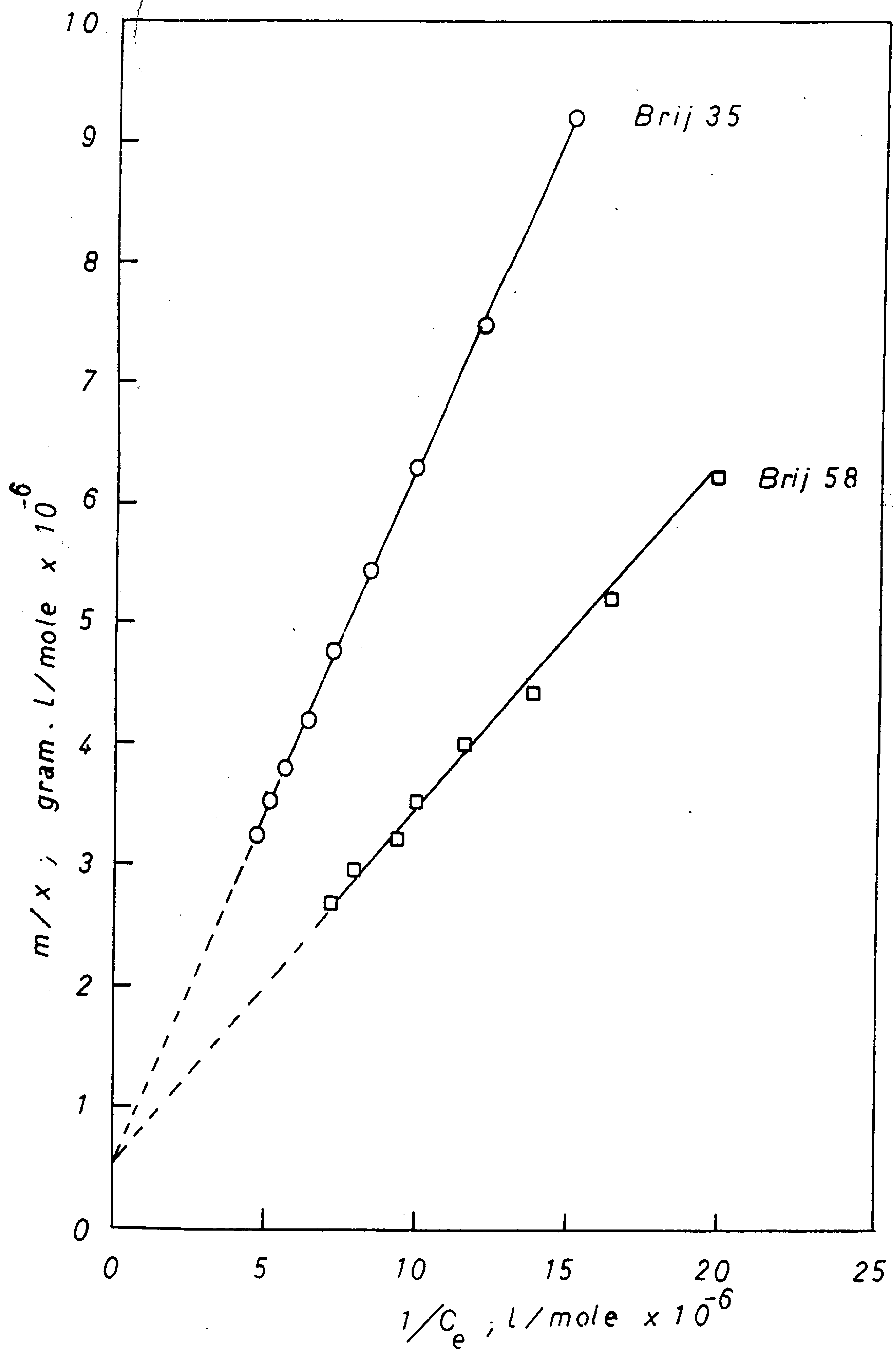

FIGURE 7: Langmuir plots for the Interaction between Rifampicin and Brijs. 


\section{REFERENCES}

1) P.H. Elworthy, A.T. Florence and C.B. Mc farlane, "Solubilization by Surface Active Agents", Champan and Hall, London, England, 1958, Ch. 4, pp. 187.

2) M.C. Meyer and D.E. Guttman, J. Pharm. Sci., 57, 1627 (1968).

3) M.C. Merrer and D.E. Guttman, J. Pharm. Sci., 58, 33 (1969).

4) M.C. Meyer and D.E. Guttman, J. Pharm. Sci.,59, 39 (1970).

5) F. Bottari, G. Dicolo, E. Nannipieri, M.F. Saettone and M.F. Serafini, J. Pharm. Sci., 64, 946 (1975).

6) F.S. Habib, S. Ismail, S. El-Shanawany and E.A. Fouad, Bull. Pharm. S... Ass. Univ., 9 (2), 144 (1986).

7) H.A. El-Sourady, F.S. Habib and S. Ismail, Pharmazie, 40, 557 (1985).

8) S.A. Said, H.I. Al-Shora and A.M. Shibl, Pharm. Ind., $\overline{43}, 791$ (1981).

9) W.B. Breuninger and R.W. Goettsch, J. Pharm. Sci., 54, 1487 (1965).

10) A.AL Sharrad, F.F. Mansour, A. Abd Elbary and M.S. El-Samaligy, Egypt. J. Pharm. Sci., 24, 81 (1983).

11) S.J.A. Kazmi and A.G. Mitchell, J. Pharm. Sci., 62, 1299 (1973).

12) K. Ikeda, K. Kato and T. Tukamoto, Chem. Pharm. Bull.,19, 2510 (1971).

13) R. Withington and J.H. Collett, J. Pharm. Pharmac., Suppl., 24, 131P(1972).

14) N.K. Patel, Can. J. Pharm. Sci., 2, 97 (1967).

15) S. Ismail, Master Thesis, Assiut University (1978).

16) S. Ismail, F.S. Habib and M.A. Attia, Acta Pharm. Fenn.,94, 163 (1985).

$17)$ I. Langmuir, J. Amer. Chem. Soci., 39, 1848 (1917); through J. Pharm. Sci., 58, 147 (1969). 


\section{تفاعل الريفامبيسين مع الـزئيسات الكبيرة \\ r - ميرجات وبيرجـــات}

سيد اسماعيل ، فوزية سيد أحمد حبيب ، سهير الشنوالسىوايههاب أحمد مواد الصيدلانيـت - كلية الصيدلة - جامعة أسيوط

تـــم فى هذا السبحث دراسة معدل نفـاد الزيفـامبيسين من خلال غشاء مسلوفـانسـى

قيـاسى وذلك فى وجود بعض المنشطـات السطحية الغير متأينه مثل ميرج or rميرجr

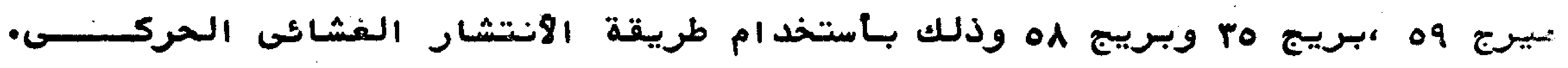
ولسقد لـوحظ أن وجود هذه المنشطات السطحية قد قلل من ثابت معدل الـفـاذ للدواء وأن العلاقة ببين ثابت معدل السنفـاذ وتركيز المنشط السطحى هى علاقة عكسيـة وأن اقـل معدل أنتشار قد لوحظ فى وجود بريج ro

تـــم رسم علاقة لانجمير فـاوضحت وجود جز" مقطوع من الـمحور الصادى ممس يسـل

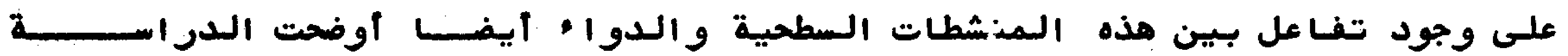
أن وجود الـمنشط السطحى يقلل من نشاط الدواء الحيوى ضد ستـيلـوكوكس أوريـــــوس

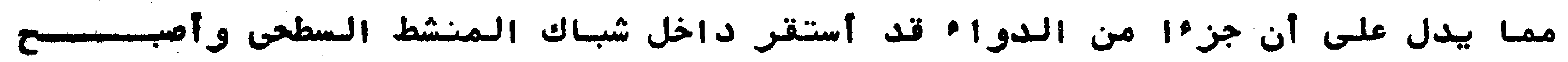

